
\title{
ZS Research Square \\ Value Chain Analysis of Smallholder Dairy Production in Debark District, Ethiopia
}

Betelhem Tsedalu Adane ( $\nabla$ betelhemtsedalu@gmail.com )

University of Gondar

Abebaw Abibo Getu

University of Gondar Faculty of Agriculture

Zework Akililu

University of Gondar Faculty of Agriculture

Fikremariam Birara Feleke

University of Gondar Faculty of Agriculture

Research

Keywords: Value chain, dairy, value chain map, value added

Posted Date: October 2nd, 2020

DOl: https://doi.org/10.21203/rs.3.rs-84177/v1

License: @ (i) This work is licensed under a Creative Commons Attribution 4.0 International License. Read Full License 


\section{Abstract}

\section{Introduction}

Milk production in Ethiopia is done largely by the smallholder farmers in the high lands and in low land areas of the country. However, the Ethiopian dairy production and market systems face severe constraints like poor genetics, insufficient access to proper animal feed and poor management practices all contribute to the low productivity levels. Similarly, dairy producers and downstream actors in the value chains face many challenges in getting milk to market. Hence this study analyzes dairy products value chain.

\section{Methods}

Value chain analysis framework and financial analysis were used.

\section{Result and conclusion}

The dairy value chain is complex involving multiple actors and their interaction. The major direct actors include input suppliers, small holder farmers, village collectors, cooperatives, semi processors, hotel and cafés and consumers. Besides indirect actors such as supportive and regulatory service providers are also involved. Though all actors have positive profit margin, the largest share goes to hotel and cafés. The financial analysis along the entire value chain shows that Producing and marketing of dairy products is profitable and creates higher value added. Concerned body should improve access to services and collective actions to enhance local value additions and Smallholder milk producers must be organized into dairy cooperative groups and subsequently into dairy unions.

\section{Introduction}

Ethiopia is reported to be endowed with the largest livestock population in Africa. According to the 2010 report of the Central Statistical Agency (CSA) the cattle population was estimated at about 50.9 million. The indigenous breeds accounted for 99.19 percent, while the hybrids and pure exotic breeds were represented by 0.72 and 0.09 percent, respectively. The CSA survey further indicates that $12 \%, 2.8 \%$ and $30 \%$ of the cattle, goat and camel population, respectively, are kept for milk production. Annual milk production is estimated at 2.8 billion liters from cattle and 165.12 million liters from camels. The dairy sector constitutes about $13.7 \%$ of the total agricultural production and $39.4 \%$ of the total livestock production in 2011 (FAOSTAT).

Smallholder dairy farming, which is defined here as production, on-farm processing and marketing of milk and milk products, in Ethiopia can be broadly classified into the lowland system, comprising the pastoral and agro-pastoral systems, and the highland system in the mixed crop-livestock areas (Azage et al. 2013). 
Ethiopia has a complex dairy value chain, with both formal and informal channels. Only $5 \%$ of the milk produced in Ethiopia is sold in commercial markets. The dairy value chain has a variety of entrepreneurial actors - smallholder and commercial producers, small and large processors, service and inputs providers, farmers' organizations and cooperatives. Value chain actors are investing in milk production, collection and processing, and increased demand would likely lead to increased investment. Market opportunity is anticipated to lead to value chain deepening and upgrading, more solid horizontal and vertical relationships, and investment in core value chain operations as well as needed services and inputs (Ponguru and Nagalla V, 2016). Smallholder farmers in the highlands produce fresh milk and processed products such as butter and local cheese (ayib). In the rural areas, fresh milk is used for household consumption, and processing into butter and sold in near or far away markets. Zegeye (2003) also asserts that butter dominates dairy marketing and the transaction in the form of raw milk is limited to the surroundings of major urban centers.

The low consumption of milk and milk products coupled with the huge potential for dairy development clearly indicates that there is ample opportunity to improve the sector. This is even more appealing given the considerable potential of dairy production in creating income-generation opportunities and its further contribution in improving human nutrition, particularly for women and children (Ahmed et al. 2004).

According to Gizaw et al., 2016 the major constraints were low scale of production, low productivity that varies across systems, failure to maintain exotic inheritance at farm level resulting in herds with mixed genotypes which are not amenable to recommendation for value chain interventions, least access by the rural system to artificial insemination (AI) service and questions by the urbanites on its efficiency, heifer supply least satisfactory among breeding services, concentrate feed cost threatening urban/peri-urban dairies, unhygienic milk handling and consumption, particularly in rural areas, price of milk generally too low for producers, especially for rural farmers.

On the other hand, the dairy sub-sector is currently facing a number of problems that have persisted for decades. Productivity of the dairy herd is low (CSA, 2008). The population of exotic and crossbred dairy cows accounted for less than $1 \%$ of the total dairy cattle. High mortality rates occur due to poor nutrition which makes cattle vulnerable to disease. Producers in the rural areas lack access to markets and extension services which reduces the ability of smallholder producers to be competitive. Feed production and distribution is not coordinated. (Tefera, 2010). Moreover, market-orientation of the production systems and the possibility of exporting Ethiopian dairy products are limited by high transaction costs despite low costs of production (Ahmed et al. 2004). Development of a vertically integrated and coordinated milk value chain is thus an important option to reduce operational and transaction costs to meet consumers' demand and to encourage partnerships along the chain (Costales et al. 2006).

There is a serious concern, however, that smallholder agricultural producers are often excluded from participation in value chain since they usually lack access to credit, make limited investment in their human capital (including skills and entrepreneurship training), and are isolated by physical distance from the market (Mendoza and Thelen, 2008). 
The general objective of this study is to analyze dairy value chain in Debark district, North Gondar zone, Ethiopia. Specifically, to identify and examine the actors involves their functions, interactions and market channels along the value chain, and to estimate the distributional equity and value added along the value chain (profit margins along the $\mathrm{VC}$ ).

\section{Research Methodology}

\subsection{Description of the study area}

The value chain analysis was conducted in Debark district, located in the former North Gondar zone of Amhara National regional state (ANRS) of Ethiopia. It is located at about $80 \mathrm{~km}$ north east of Gondar town. According to the agro ecological classification used in Ethiopia, the climatic condition of the city is characterised as Dega climatic zone. Average annual rainfall of the district is about $1200 \mathrm{~mm}$. The mean annual temperature ranges from $12.90 \mathrm{C}$ to $26.40 \mathrm{C}$. The households engaged in raring animals and plantation activities. Production of milk is a widespread economic activity in the area which is the major source of livelihood for numerous smallholder farmers in terms of subsistence uses and cash income generation.

\subsection{Sampling technique and sample size}

Sampled smallholder householders were selected using a multi-stage sampling. In the first stage Debark District was selected purposively due to potential area in dairy production, three kebeles (Debir, yekirar and Mikara) were selected purposively in discussion with district agricultural office experts due to being a potential Kebeles and better experience in dairy production. Then a total of 60 households were selected randomly and proportional to number of producing households using the list of dairy producer inhabitants in the Kebele. Moreover, 20 sample traders (village collectors, cooperatives, café and restaurants and semi processors) were selected by using snow ball sampling method.

\subsection{Data source and data collection method}

This study employed both primary and secondary data relevant to answer the research objectives. Primary data were collected using interview schedule and key informant interview checklists for the focus group discussion. It was collected from sample household head farmers and value chain actors such as traders at different levels along the value chain. Secondary data was collected and reviewed from published and unpublished official sources such as the district administrative and agricultural office report.

\subsection{Method of data analysis}

Data were analyzed by using both descriptive statistics and econometrics analyses. The value chain analysis was carried out first by identifying the actors and activities in the chain, examining the roles played by each actor and the mapping the flow of the dairy products. Then estimation of profits margins, and value added within the actors at different stages of the value chain, dictating the possible upgrading 
mechanisms and identification of strengths, opportunities, weaknesses and threats in the value chain were analyzed.

Quantitative data on the cost and revenue structures, value added, benefit distribution was analyzed by calculating using the expressions briefly by (Marshall et al., 2006). Profit margin at each stage was calculated to evaluate the benefits along the value chain actors.

Profit margin $=$ Revenue - total cost

Where, Revenue $=$ sale volume $*$ unit price

$$
\begin{aligned}
& \text { Profit margin } \%=\frac{\text { Revenue-totalcosts }}{\text { Revenue }} * 100 \\
& \text { commercializationmargin }=\frac{\text { sale price- } \text { purchase price }}{\text { end } \text { market price }} 100
\end{aligned}
$$

Value added can be broken down into different segments of the value chain as net profits, the amount of personal remuneration and taxes (Vedeld et al, 2004). Accordingly, value added is not just an element of income but it also represents the distribution of that income amongst the fundamental agents of the national economy: households (the recipients of the return to labor), financial institutions (interest charges), government administration (taxes), and enterprises (gross or net profit) (Tallec and Bockel 2005; Vedeld et al, 2004).

\section{Results And Discussion}

\subsection{Socioeconomics and institutional characteristics}

The average age of the smallholders was 47.58 years with standard deviation of 11.7391(Table 1). The result also indicated that the small holder producers were within the age range of 22 and 75 years. Regarding to the family size, the respondent households had an adult equivalent that ranging from 1.2 to 10.5 and the average adult equivalent ratio is found to be 5.21 persons. The mean land size was 2.99 ha total farm land. The experience of the smallholder producers in dairy production ranges from 1 to 40 years. The smallholder producers on average had 5.13 years of experience in dairy production. 
Table 1

characteristics of smallholder householders

\begin{tabular}{|lllll|}
\hline Variable & Mean & Std. Dev. & Min & Max \\
\hline Age & 47.58333 & 11.7391 & 22 & 75 \\
\hline Farm size & 5.214407 & 2.047603 & 1.2 & 10.5 \\
\hline Dairy experience & 5.157895 & 7.140902 & 1 & 40 \\
\hline Land size & 2.995833 & 2.887176 & 0.25 & 15 \\
\hline
\end{tabular}

The survey result showed in Table 2 that $83.33 \%$ of the farmers had got extension service and it also revealed that $71.67 \%$ of the farmers was participating in the training on dairy production and processing from OoARD, DA's and NGOs (). $88.33 \%$ of the respondents had not access to credit. Among the small holder farmers, $38.33 \%$ had not a contractual agreement, while more than $61 \%$ of the smallholder farmers had not a contractual agreement this indicates there is a high demand of milk. More than half $(56.67 \%)$ of smallholder farmers were member of dairy cooperatives.

Table 2

Access to services

\begin{tabular}{|llll|}
\hline Variables & Categories & Frequency & Percent \\
\hline Access to extension services & Yes & 50 & 83.33 \\
\cline { 2 - 4 } & No & 10 & 16.67 \\
\hline Access to credit & Yes & 7 & 11.67 \\
\cline { 2 - 4 } & No & 53 & 88.33 \\
\hline Access to training & Yes & 43 & 71.67 \\
\hline \multirow{2}{*}{ Contractual Agreement } & No & 17 & 28.33 \\
\hline & Yes & 37 & 61.67 \\
\hline Member of cooperatives & No & 23 & 38.33 \\
\hline & Yes & 34 & 56.67 \\
\hline
\end{tabular}

\subsection{Dairy Value Chain}

The simplified value chain map of milk originating from Debark district is illustrated in Fig. 1. There is a complex chain that the woodlot products flows and different direct and indirect actors were involved until it delivered to the final consumer. The value chain map shows the multiple direct and indirect actors involved and interacting in the dairy value chain. 
Diverse group of actors including the producers, traders and support and regulatory service providers are involved in the value chain to give services like concentrate feeds (industrial by-products) and green fodder Artificial Insemination (Al), veterinary and credit services/finance, land and labor which are supplied by smallholder farmers, District Agriculture Office, veterinary clinics and NGOs (International Livestock Development Project ). The indirect actors mainly serve support and regulatory services along the value chain. These were the actors who enabled the value chain to be performed successfully in the way that facilitating by providing extension services, credit access, training, market information and trade license.

Farmers- are dairy producers who are actively engaged in production and marketing of dairy products and they are major actors and have performed many functions starting from dairy cow selection, providing feedings, building shelter up to milking, processing the milk traditionally and selling it to the market. They sold the surplus milk produced to the local markets, either as liquid milk or in the form of butter or cheese.

Village collectors- are the local traders who collected milks from smallholder farmers. They sold the outputs directly to the cooperatives, hotels and consumers in the district. Collecting the raw milk from milk producer farmers in the study area is the major functions of village traders. Most of milks produced are purchased from farmers by village traders.

Dairy cooperatives- They collected milk from village collectors and its members. In the process of milk collection and bulking, lactometer test is applied to assure the quality of milk and it is one of the guarantees to keep the market since consumers are relied on. They add a value like change the raw milk in to yoghurt and butter.

Semi processors- In the district there was only one semi processing actor it had many roles in milk value chain. Smallholder farmers and producers are a source of milk for this semi processor company. In the process of milk collection, they conduct lactometer test to check the quality of milk. They did semi processing activities like change the form of the milk, packing and pasturalizasion. They delivered the dairy products to hotel and cafes, and consumers in the district.

Hotel and cafes- they are the last link deliver the dairy products to the consumers in Debark District. They got the milk from all actors involved in milk value chain. They sold all milk products directly to consumers.

Consumers- These are individual households, living in the area and restaurant and hotels. They bought the commodity for their own consumption. They bought from Farmers, semi processors, cooperatives, and hotel and cafés.

\subsection{Cost, Benefit Share and Value Added along Dairy Value Chain}

The average profit margin was computed by estimating the cost and revenue of actors in the value chain. Financial performance or profitability is analyzed by considering the average cost and revenue of milk 
production and marketing along the value chain actors starting from Debark district. In this study, the cost benefit share and value added along the value chain actors was done for the longest and larger quantity of milk transmitted channel. Because in this channel many actors are involved and larger amount of milk transacted.

Table 3

Smallholder farmers' costs, profit margin and value added along the chain

\begin{tabular}{|l|lll|}
\hline Average quantity of milk produced per farmer monthly = 2 cows = 172 liter & & \\
\hline Cost items, price and income & $\begin{array}{l}\text { Birr/2 } \\
\text { cow }\end{array}$ & Birr/cow & Birr/liter \\
\hline Total production and marketing cost & 2118 & 1059 & 12.31 \\
\hline $\begin{array}{l}\text { Production materials (breeding, shelter, feeding, veterinary } \\
\text { services, equipment....) }\end{array}$ & 1924 & 962 & 11.19 \\
\hline Labor cost (opportunity cost) & 150 & 75 & 0.87 \\
\hline Transportation cost & 44 & 22 & 0.26 \\
\hline Tax & no & no & no \\
\hline Average farm gate price (weighted mean Birr/litter) & 13 & & \\
\hline Total gross revenue (price*sale) & 2236 & 1118 & 13 \\
\hline Net profit (Revenue less total cost)(Birr) & 118 & 59 & 0.69 \\
\hline Profit margin (\%) & 5.27 & & \\
\hline Value added (Birr) & 268 & 134 & 1.56 \\
\hline Source: Own survey data, 2018 & & & \\
\hline
\end{tabular}

As displayed in Table 3, the labor cost (opportunity cost of labor) and production material cost accounts to about $7.1 \%$ and $90.8 \%$ of the total production and marketing cost at farm gate level, respectively. Transportation cost accounts to $1.9 \%$ of the costs at farm gate level. The largest share of the production and marketing cost at farm gate level was taken by production cost. For the smallholder farmers, dairy production is economically profitable, average net annual income earned was 59 birr per liter and making about $59.27 \%$ of profit margin.

The traders which are village collectors, semi processors and hotel \& cafés earned a positive net profit margin. From all actors involved in the dairy value chain actor's hotel \& cafés got highest profit margin and they are more beneficiary in milk marketing activity along the dairy value chain in Debark district. 
Table 4

Marketing costs and benefit share of traders

\begin{tabular}{|lllllll|}
\hline Cost items and price & \multicolumn{2}{l}{ Village collectors } & \multicolumn{2}{l}{ Semi processing } & \multicolumn{2}{l|}{ Hotel and cafés } \\
\cline { 2 - 7 } & $\begin{array}{l}\text { Total } \\
\text { (Birr) }\end{array}$ & $\begin{array}{c}\text { Per } \\
\text { liter }\end{array}$ & $\begin{array}{l}\text { Total } \\
\text { (Birr) }\end{array}$ & $\begin{array}{c}\text { Per } \\
\text { liter }\end{array}$ & $\begin{array}{l}\text { Total } \\
\text { (Birr) }\end{array}$ & $\begin{array}{c}\text { Per } \\
\text { liters }\end{array}$ \\
\hline $\begin{array}{l}\text { Average quantity handled (milk per } \\
\text { liter ) }\end{array}$ & $\mathbf{1 2 7 5}$ & & 1650 & & 1791 & \\
\hline Purchase of the product & 16575 & 13 & 21450 & 13 & 23283 & 13 \\
\hline Labor cost (processing) & 300 & 0.23 & 6040 & 3.66 & 3200 & 1.79 \\
\hline Transportation cost & 475 & 0.37 & Na & Na & Na & Na \\
\hline Equipment and machinery & 520 & 0.41 & & & 7500 & 4.18 \\
\hline Taxes and fees & Na & Na & 625 & 0.37 & 340 & 0.19 \\
\hline Electricity & Na & Na & 2500 & 1.5 & 600 & 0.35 \\
\hline Total Marketing costs & 1295 & 1.01 & 9165 & 5.53 & 11640 & 6.57 \\
\hline Total costs & 17870 & 14.01 & 30615 & 18.53 & 34923 & 19.57 \\
\hline Average selling price & 15 & & 28 & & 30 & \\
\hline Gross revenue (quantity*selling \\
price)
\end{tabular}

\subsection{Value addition and its proportion}

Distribution of value added to different actors in the value chain is presented by the Table 2; the total average value added was estimated at about 30.66 birr per litter. The largest proportion of value was created by semi processors and accounted at about $48 \%$ of the total average value added by the traders and smallholder farmers or producers. Accordingly, hotels and cafés (42\%) constitute the next largest proportion of total value creation. The value created by the village collectors and small holder farmers was about 21 and $17 \%$ respectively of the total average value added.

\subsection{Price and commercialization margin}

The Table 5 showed the distribution of commercialization margins among dairy marketing actors in the value chain. The total commercialization margin and the price used by all marketing actors was estimated 17 birr per liter. 
Table 5

Price distribution and commercialization margin along the value chain

\begin{tabular}{|llll|}
\hline Category of actors & weighted average price (Birr/pole) & \multicolumn{2}{l|}{ Commercialization Margin } \\
\cline { 3 - 4 } & & birr/liter & $\%$ \\
\hline Small holder farmers & 13 & & 43.3 \\
Village collectors & 15 & 2 & 6.7 \\
\hline Semi processors & 28 & 13 & 43.3 \\
\hline Hotels and café & 30 & 2 & 6.7 \\
\hline Total & & 17 & 100 \\
\hline Source: Own survey data, 2018 & & \\
\hline
\end{tabular}

From Table 5, Semi processors had highest value increment in the price spread analysis because much of processing activities was done in this level. From the total commercialization margin smallholder Farmers and semi processors got the largest share which is about $43.3 \%$ of birr per liter.

\section{Conclusions And Recommendations}

Dairy production and marketing is a major source of livelihood for different actors in the area. All actors in the value chain had positive profit and value added. So, dairy production and marketing was profitable. Semi processors were created larger proportion of value addition and they were more beneficiaries in dairy marketing than other actors involved in the value chain. Small holder farmers and actors in the value chain face many challenges like price fluctuation, lack of supply, poor infrastructure like electricity, lack of awareness regarding artificial insemination and seasonal change were some of the challenges faced by value chain actors in production and marketing of milk.

In order to improve dairy value chain, there should be creating awareness on the nutritional value of milk and milk products, Smallholder milk producers must be organized into dairy cooperative groups and subsequently into dairy unions to increase milk production, the volume of milk consumed and marketed, and commercializing the subsistent type of smallholder milk production system

\section{Abbreviations}

Al: Artificial Insemination; ANRS:Amhara National regional State; CSA:Central Statics Agency; DA's:Development Agents; FAOSTAT:Food and Agriculture Organization Corporate Statistical Database; NGOs:Non Government Organizations; OoARD:Office of Agriculture and Rural Development; VC:Value Chain.

\section{Declarations}




\section{Availability of data and materials}

The authors want to declare that they can submit the data at any time based on publisher's request. The datasets used and/or analyzed during the current study were available from the authors on reasonable request.

\section{Ethical approval and consent to participate}

Ethical clearance letters were collected from University of Gondar research and community service directorate and Debark District of face to care for both the study participants and the researchers. During survey, official letters were written for each Kebele/villages, informed verbal consent was obtained from each client, and confidentiality was maintained by giving codes for each respondent rather than recording their name. Study participants were informed that clients have a full fright to discontinue or refuse to participate in the study. Hence, all participants throughout the research, including survey households, enumerators, the supervisors and key informants were fully informed of the objectives of the study. They were approached friendly in free moods until they do this research.

\section{Consent for publication}

Not applicable.

\section{Competing interests}

The authors declare that they have no competing interests.

\section{Funding}

The University of Gondar was provided financial support to complete this research successfully.

\section{Authors' contributions}

All authors were carried out "Value Chain Analysis of Smallholder Dairy Production in Debark District, Ethiopia" study, participated in proposal development, data collection and drafted manuscript. All authors read and approved the final manuscript.

\section{Acknowledgements}


The authors would like to acknowledge University of Gondar for providing fund for to cover the costs of the study.

\section{References}

Ahmed, M.A.M., Ehui, S. and Yemesrach Assefa. 2004. Dairy development in Ethiopia. Washington, DC, USA: IFPRI (International Food Policy Research Institute).

Azage T, Gebremedhin B, Hoekstra D, Belay B, Mekasha Y (2013). Smallholder dairy production and marketing systems in Ethiopia: IPMS experiences and opportunities for market-oriented development. https://cgspace.cgiar.org/handle/10568/27914

Costales A., Gerber P. \& Steinfeld H. (2006). - Underneath the livestock revolution. In Livestock report 2006. Food and Agriculture Organization, Rome, 15-27.

CSA, 2010 Agricultural sample survey. Report on crop and livestock product utilization. Central Statistical Agency (CSA) , Addis Ababa, Ethiopia.

FAOSTAT ; Food and Agriculture Organization of the United Nations.<http://faostat.fao.org/>.

Gizaw et al., 2016 Gizaw, S., Megersa, A., Muluye, M., Hoekstra, D., Gebremedhin, B. and Tegegne, A. 2016. Smallholder dairy farming systems in the highlands of Ethiopia: System-specific constraints and intervention options. LIVES Working Paper 23. Nairobi, Kenya: International Livestock Research Institute (ILRI).

Marshall E, Schreckenberg K, Newton A (eds) (2006) Commercialization of non-timber forest products: Factors influencing success: Lessons learned from Mexico and Bolivia and policy implications for decision-makers. UNEP World Conservation Monitoring Centre.

Mendoza RU, Thelen N (2008) Innovations to make markets more inclusive for the poor. Dev Policy Rev 26(4):427-458. https://doi.org/10.1111/j.1467-7679.2008.00417.

Ponguru CS Reddy and Nagalla Vidya Kanna (2016) Review of milk value chain in Ethiopia.

Tallec F, Bockel L (2005) Commodity chain analysis: Financial analysis: FAO Rome http://www.fao.org/docs/up/easypol/331/value_chain_analysis_financial_analysis_044en.

Tefera, 2010 Tesfaye Lemma Tefera, Puskur R, Hoekstra D and Azage Tegegne. 2010. Commercializing dairy and forage systems in Ethiopia: An innovation systems perspective. IPMS Working Paper 17. ILRI (International Livestock Research Institute), Nairobi, Kenya.

Vedeld P, Angelsen A, Sjaastad E, Berg G (2004) counting on the environment: Forest incomes and the rural poor. Environmental Economics Series, Vol 98, Washington, DC. 
Zegeye Yigezu. 2003. Imperative and challenges of dairy production, processing and marketing in Ethiopia. In: Jobre, Y. and Gebru, G. (eds), Challenges and opportunities of livestock marketing in Ethiopia. Proceedings of the 10th annual conference of the Ethiopian Society of Animal Production (ESAP) held in Addis Ababa, Ethiopia: ESAP.

\section{Figures}

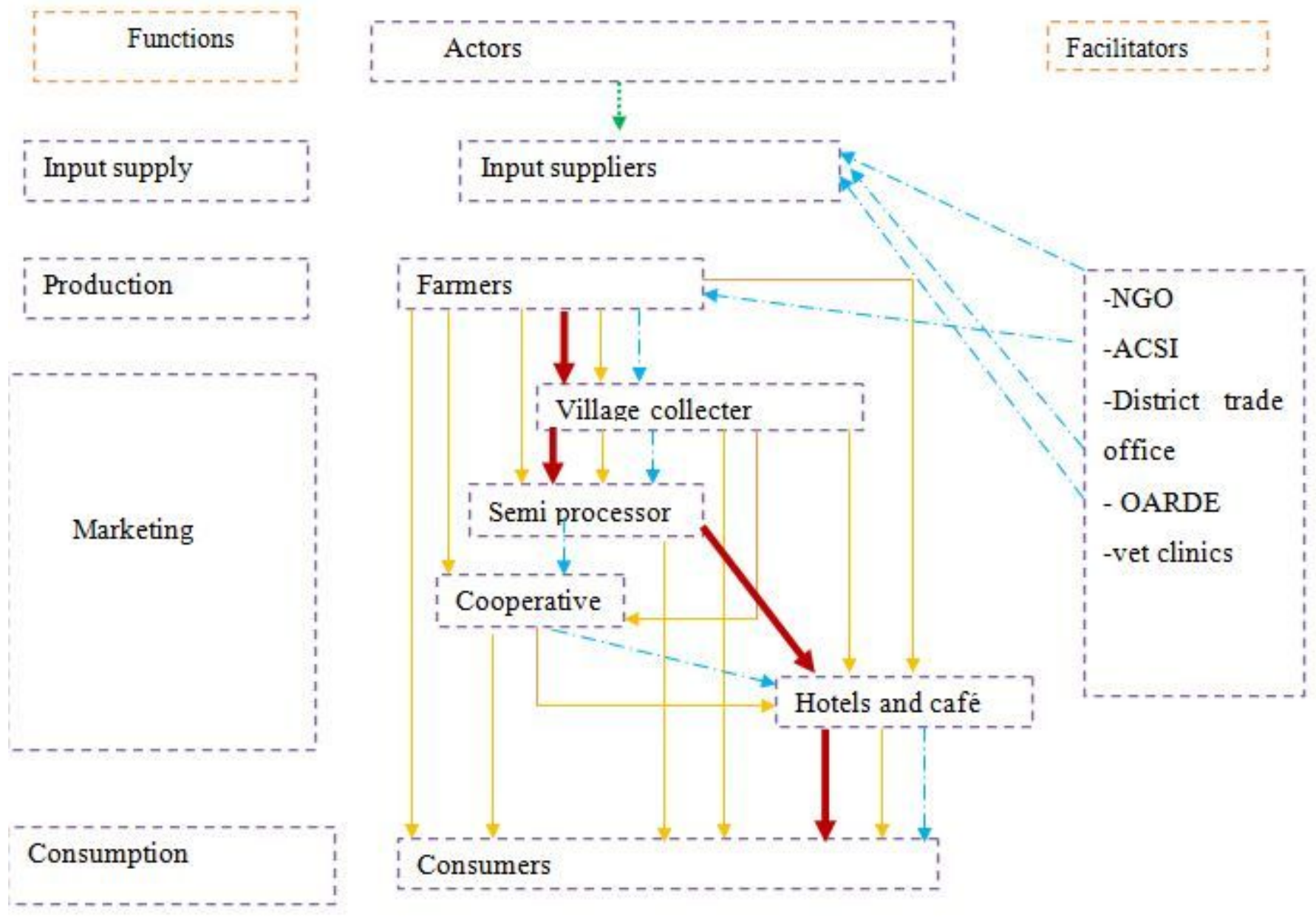

Key $\longrightarrow$ Represents physical flow of milk

Represents support services

Represents the flow of greater quantity of milk

Source: Own survey result, 2018

Figure 1

Milk value chain map in Debark district 